\title{
The influence of age and gender of student motorcycle riders on traffic violations and accidents using a structural equation model
}

\author{
I Wayan Suteja ${ }^{1, *}$, Mifta Holman $^{1}$, D.M. Priyantha Wedagama $^{2}$, and P. Alit Suthanaya ${ }^{2}$ \\ ${ }^{1}$ Civil Engineering Department, University of Mataram, 83126, Mataram, Indonesia \\ ${ }^{2}$ Civil Engineering Department, University of Udayana, Denpasar Bali, Indonesia
}

\begin{abstract}
During the last three years, traffic accidents in Mataram CityLombok have increased significantly. Interestingly, most of the accidents were involved high school motorcyclist. This study aims to investigate the influence of age and gender of student motorcycle riders on traffic violations and accidents, which represents a city with moderate growth. The investigation was conducted using a questionnaire survey, in which the data were collected from 394 students covering eighteen high schools. The model developed consists of behavioral, violation and accident latent variables. Behavioral constructs are comprised of five observed variables, the violation constructs consist of three observed variables, and accident constructs have two observed variables. It was found that $51.53 \%$ from $87.5 \%$ of the student's motorcycle riders did not have the proper riding license, whom has age under 17 years old and had been involved in traffic accidents. The study was indicated a significant relationship between student riding behavior to traffic violations, and between traffic violations to accidents. Gender and age show differences in the significance (chi-square) values between riding behaviors relationship to traffic violations and accidents too.
\end{abstract}

\section{Introduction}

Most traffic accidents are caused by the driver, so driver behavior has an obvious effect on accidents and traffic violations. Accident are often preceded by traffic violation behavior $[7,8,9]$. A traffic violation can be defined as an intervening variable (mediation variable) between driving behavior that caused a traffic accident $[5,7]$. Violations and traffic accidents in Mataram City mainly involved high school motorcyclists. Therefore, there is a strong need to study, how much influence driving behavior has on the traffic accidents of student's motorcycle riders in Mataram City. During the last three years, the number of traffic accidents in Mataram City-Lombok have increased significantly. Based on data from the last three years, accidents involving drivers based on the age. The ages of 16-30 have increased from 225 cases in 2015, to 311 cases in 2016 and 417 cases in 2017. This range of ages is different from the research conducted in England, where young male drivers (18-25) and older male

* Corresponding author: w.suteja@gmail.com 
drivers' (35-50) perceptions of their driving risk and confidence in their driving ability were compared. Both of groups showed different conceptions of their own accident risk, further generating subjective ratings of risk of accident with fatality injury rate. The number of accident victims based on gender from 2015 to 2017 is presented in Table 1.

Table 1. Accident victims based on gender 2015 -2017.

\begin{tabular}{|c|c|c|c|c|c|c|c|}
\hline \multirow{2}{*}{ Year } & \multicolumn{6}{|c|}{ Accident Victim based on Gender } & \multirow{2}{*}{ Total } \\
\cline { 2 - 7 } & \multicolumn{3}{|c|}{ Male } & \multicolumn{3}{|c|}{ Female } & \\
\cline { 2 - 7 } & F & SI & MI & F & SI & MI & \\
\hline 2015 & 32 & 1 & 63 & 2 & - & 12 & 110 \\
\hline 2016 & 41 & - & 93 & 3 & - & 31 & 168 \\
\hline 2017 & 31 & - & 60 & 3 & - & 13 & 107 \\
\hline \multirow{2}{*}{ Total } & 104 & 1 & 216 & 8 & 0 & 56 & \multirow{2}{*}{385} \\
\cline { 2 - 6 } & \multicolumn{3}{|c|}{321} & \multicolumn{3}{|c|}{64} \\
\hline
\end{tabular}

Note: $\mathrm{F}=$ fatalities

$\mathrm{SI}=$ serious injuries

$\mathrm{MI}=$ minor injuries

In addition, the number of accident victims sorted by age, in 2017, is shown in Table 2.

Table 2. Victim that riding motorcycles (based on age group) in NTB in 2017.

\begin{tabular}{|c|l|c|c|c|c|c|c|c|}
\hline \multirow{2}{*}{ No } & \multirow{2}{*}{ Police Resort of } & \multicolumn{6}{|c|}{ Age group of victims (years old) } & \multirow{2}{*}{ Total } \\
\cline { 2 - 8 } & $\mathbf{0 0 - 0 9}$ & $\mathbf{1 0 - 1 5}$ & $\mathbf{1 6 - 3 0}$ & $\mathbf{3 1 - 4 0}$ & $\mathbf{4 1 - 5 0}$ & $\begin{array}{c}\text { Above } \\
\mathbf{5 1}\end{array}$ & \\
\hline 1 & City of Mataram & 11 & 33 & 159 & 56 & 40 & 49 & 348 \\
\hline 2 & $\begin{array}{l}\text { Regency of Lombok } \\
\text { Barat }\end{array}$ & 6 & 6 & 55 & 16 & 20 & 23 & 126 \\
\hline 3 & $\begin{array}{l}\text { Regency of Lombok } \\
\text { Tengah }\end{array}$ & 13 & 24 & 98 & 38 & 20 & 43 & 236 \\
\hline 4 & $\begin{array}{l}\text { Regency of Lombok } \\
\text { Timur }\end{array}$ & 42 & 81 & 304 & 74 & 52 & 100 & 653 \\
\hline 5 & $\begin{array}{l}\text { Regency of West } \\
\text { SBW }\end{array}$ & 4 & 11 & 29 & 18 & 6 & 7 & 75 \\
\hline 6 & $\begin{array}{l}\text { Regency of SBW } \\
\text { BESAR }\end{array}$ & 19 & 43 & 132 & 39 & 30 & 54 & 317 \\
\hline 7 & Regency of Dompu & 10 & 15 & 73 & 26 & 13 & 25 & 162 \\
\hline 8 & Regency of Bima & 15 & 13 & 40 & 21 & 12 & 28 & 129 \\
\hline 9 & City of Bima & 6 & 20 & 68 & 15 & 16 & 24 & 149 \\
\hline 10 & $\begin{array}{l}\text { Regency of Lombok } \\
\text { Utara }\end{array}$ & 4 & 4 & 27 & 14 & 11 & 6 & 66 \\
\hline \multicolumn{2}{|c|}{ Total } & 130 & 250 & 985 & 317 & 220 & 359 & 2,261 \\
\hline
\end{tabular}

The increase in the number of accidents and fatalities during the last three years was significant enough to merit this research. Several methods can be used to analyze the effect of driving behavior on traffic accidents according to age and gender $[4,5,7,9,10]$, one of which is the Structural Equation Modelling (SEM) method. Structural Equation Modelling (SEM) is a multivariate analysis used to understand the relationship between complex variables $[5,8]$. In this analysis, the researcher used the SEM method with the help of AMOS software. AMOS software's main advantage is it user friendliness.

The objectives of this research are as follow:

a. To investigate the influence of high school students' behavior on traffic violations in

Mataram City. 
b. To evaluate the impact of violations on traffic accidents in Mataram City, comparing differences in age and gender.

\section{Literature review}

\subsection{Definition of traffic violation and traffic accident}

Traffic violations are action contrary to traffic laws [1], either intentionally or negligently committed. According to Indonesian Traffic Law No. 22 of 2009 [1], from the Road Traffic and Transportation Laws, traffic accidents are an unexpected and unintentional accident involving vehicles, with or without other road users, resulting in human casualties and/or property damage. According to Dwiyogo and Prabowo (2006), traffic accidents can be defined as incidents in road traffic at least one vehicle, where the damage done is detrimental to the owner or the victim $[3,7,8]$.

\subsection{Traffic accident factors and driver behavior}

Accident factors are identical to traffic-forming elements, i.e. road users, vehicles, roads, and environmental conditions. According to Warpani (2002) in Ikroom (2014), the main cause of majority of accidents in Indonesia is the human factor, either due to the negligence or neglect of motorists or the deliberate disobedience of traffic law on public roads [6]. According to Lulie (2005) in Wesli (2015), driving behavior is defined as the behavior of the owner or user in driving and caring for a vehicle $[8,7,5]$. How a person drives has a significant impact on whether or not there will be an accident. Meanwhile, according to Dwiyogo and Prabowo (2006), driver behavior comes from the interaction of human factors with other factors like vehicle condition and the road environment [3]. The difference in driving behavior between men and women is the influence of uncontrolled negative emotions $[9,10]$

\subsection{Initial of research model}

The multivariate statistical technique [5] is a combination of factor and regression analysis (correlation), to test the inter-variable relationships in a model. This relationship is either inter-indicator with its construct, or between constructs. Researchers built a model based on the theories that have been discussed in the previous literature review. The relationship model between variables is depicted in Figure 1.

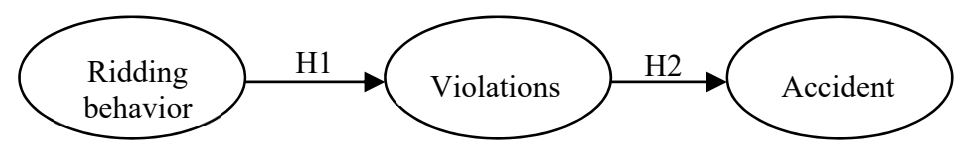

Fig. 1. Initial model of research.

The initial hypothesis of the study:

The hypothesis of this study is as follows:

H1: Driving behavior positively affects the number of traffic violations.

$\mathrm{H} 2$ : Traffic violations have a positive effect on traffic accidents.

\subsection{Validity test}

The instance is valid if the value of $\mathbf{r}$ count $>\mathbf{r}$ table and the questionnaire instrument can be used for data collection. Conversely when $\mathbf{r}$ arithmetic $<\mathbf{r}$ table, then the instance is declared 
invalid and no longer used in data collection. The formula used for a validity test using product of moment technique is:

$$
\mathrm{r}_{\mathrm{XY}}=\frac{\sum \mathrm{XY}}{\sqrt{\left(\sum \mathrm{X}^{2}\right)\left(\sum \mathrm{Y}^{2}\right)}}
$$

where:

$\mathrm{R} \quad=$ relation coefficient.

$\mathrm{X}=$ The first score, in which case $\mathrm{X}$ is the scores on the item to be tested for its validity.

$\mathrm{Y}=$ The second score, in this case $\mathrm{Y}$ is the number of scores by each respondent.

$\Sigma X Y=$ Number of first score multiplication result with second score.

$\Sigma \mathrm{X}^{2}=$ Quantity of first scores result.

$\Sigma \mathrm{Y}^{2}=$ Quantity of results of the second scores.

In this research, validity testing was done with using the SPSS program. The validity of each item can be seen by the corrected item-total correlation value for each question.

\subsection{Reliability test}

Reliability is the extent to which the measurement results remain consistent, through multiple repetitions of the experiment with matching tools and circumstances. A research instrument is said to be reliable when the reliability coefficient ( $\mathbf{r} 11)$ is $>0.6$ or greater than the $\mathbf{r}$ table (Sugiyono, 2010). The stability calculation tests reliability by using Cronbach's alpha technique:

$$
\mathrm{r}_{11}=\left[\frac{\mathrm{k}}{\sqrt{(\mathrm{k}-1)}}\right]\left[1-\frac{\sum \sigma \mathrm{b}^{2}}{\sigma 1^{2}}\right]
$$

where:

$\mathrm{r}_{11}=$ reliability instrument

$\mathrm{k} \quad=$ the number of questions

$\Sigma \sigma b^{2}=$ number of variance point

$\sigma 1^{2}=$ all of variance

Table 3. The level of reliability is based on the alpha values.

\begin{tabular}{|c|c|}
\hline Alpha & Reliability Level \\
\hline $0.00-0.20$ & Less reliable \\
\hline$>0.20-0.40$ & Somewhat reliable \\
\hline$>0.40-0.60$ & Quite reliable \\
\hline$>0.60-0.80$ & Reliable \\
\hline$>0.80-1.00$ & Very reliable \\
\hline
\end{tabular}

Source: Sugiyono, 2010

\section{Research methods}

\subsection{Research areas, samples, variables and indicators}

This research was conducted with a sample of 394 student riders covering eighteen high schools in Mataram City, and several variables were used:

a. Exogenous variable (dependent variable), driving behavior

b. Intermediate variable (intervening variable), i.e. the traffic violation 
c. Endogenous variable (independent variable), the traffic accident

To measure the latent variables of research required a manifest variable or an indicator.

Table 4. Research variables and indicators.

\begin{tabular}{|c|l|c|}
\hline RESEARCH VARIABLE & \multicolumn{1}{|c|}{ INDICATOR } & SIMBOL \\
\hline \multirow{4}{*}{ Driving Behavior } & Discipline in driving & $\mathrm{X} 1$ \\
\cline { 2 - 3 } & Driving skills & $\mathrm{X} 2$ \\
\cline { 2 - 3 } & Emotion level & $\mathrm{X} 3$ \\
\cline { 2 - 3 } & Knowledge of driving & $\mathrm{X} 4$ \\
\cline { 2 - 3 } & Fatigue in driving & $\mathrm{X} 5$ \\
\hline \multirow{3}{*}{ Traffic Violations } & High Speed while driving & $\mathrm{X} 6$ \\
\cline { 2 - 3 } & Violation of road markers and signs & $\mathrm{X} 7$ \\
\cline { 2 - 3 } & Possession of a driver's licence & $\mathrm{X} 8$ \\
\hline \multirow{2}{*}{ Traffic Accident } & Using brakes abruptly before a crash & $\mathrm{X} 9$ \\
\cline { 2 - 3 } & Sudden change direction to avoid collision & $\mathrm{X} 10$ \\
\hline
\end{tabular}

\subsection{Sampling technique}

The population in this study consist of high school students in Mataram were actively between $2016-2017$. The total sample size come to 21,551 persons. The data were obtained from the official website Kemendikbud [2] accessed on January 24th, 2017. According Sugiyono, (2010), the sample research number can be determined by using Slovin formula:

$$
\mathrm{n}=\frac{\mathrm{N}}{1+\mathrm{N} \alpha^{2}}
$$

where:

$\alpha=$ Deviation of the desired population or degree of reliability (5\%)

$\mathrm{N}=$ Population size $(21,551$ person)

$\mathrm{n}=$ Sample Size

From the number of population data obtained the number of samples:

$$
\mathrm{n}=\frac{\mathrm{N}}{1+\mathrm{N} \alpha^{2}} \quad \rightarrow \mathrm{n}=393,7 \approx 394 \text { Samples }
$$

\subsection{Data collection method}

The data were collected via a questionnaire distributed to the student respondents. The questionnaire in this study used a Likert scale, $1-5$, to measure the attitudes of respondents towards each question. The Likert scale used in this research is as follows:

Table 5. Likert scale with score.

\begin{tabular}{|c|c|c|}
\hline \multirow{2}{*}{ Alternative Answer } & \multicolumn{2}{|c|}{ Score } \\
\cline { 2 - 3 } & positive & negative \\
\hline Never & 5 & 1 \\
\hline Ever & 4 & 2 \\
\hline Sometimes & 3 & 3 \\
\hline Often & 2 & 4 \\
\hline Always & 1 & 5 \\
\hline
\end{tabular}




\subsection{Data analysis technique}

The analysis technique used in this research was a quantitative analysis using SEM (Structural Equation Modelling) model with the help of the AMOS 22.0 program. SEM can be described as an analysis combining factor analysis [5], structural model, and path analysis, Sugiyono, (2010). According to Ghazali (2011), there are seven stages in modelling and structural equation analysis $[4,5]$, namely:

1. Theoretical model development;

2. Prepare the path diagram;

3. Change the path diagram into structural equations;

4. Selecting input matrix and model estimation

5. Assess model identification;

6. Assessing goodness-of-fit criteria;

7. Interpretation of model estimation.

\section{Results and discussions}

\subsection{Validity test for questionnaire instrument}

A validity test was used to measure if the questionnaire instrument was valid, or not. The instance is valid if the $\mathbf{r}$ count value $>r$ table value, letting the instrument can be used for data collection. Table 6 shown that, the critical value of $\mathbf{r}$ table as a Pearson's Product Moment, who known $r$ table value is 0.279 for every fifty-sample number (n) data and with significance level $(\alpha)=0.05$. The result of validity test is shown in Table 6 .

Table 6. Validity test of the questionnaire.

\begin{tabular}{|c|c|c|c|c|}
\hline $\begin{array}{c}\text { Statement for } \\
\text { behavior } \\
\text { indicator }\end{array}$ & $\begin{array}{c}\text { r value } \\
\text { calculated from } \\
\text { analysis }\end{array}$ & $\begin{array}{c}\text { r base on } \\
\text { statically table }\end{array}$ & $\begin{array}{c}\text { Number of } \\
\text { data }\end{array}$ & $\begin{array}{c}\text { Indicator } \\
\text { value degree }\end{array}$ \\
\hline P1 & 0.439 & 0.279 & 50 & Valid \\
\hline P2 & 0.375 & 0.279 & 50 & Valid \\
\hline P3 & 0.478 & 0.279 & 50 & Valid \\
\hline P14 & 0.618 & 0.279 & 50 & Valid \\
\hline P15 & 0.486 & 0.279 & 50 & Valid \\
\hline P19 & 0.404 & 0.279 & 50 & Valid \\
\hline P20 & 0.297 & 0.279 & 50 & Valid \\
\hline P21 & 0.554 & 0.279 & 50 & Valid \\
\hline P24 & 0.143 & 0.279 & 50 & Invalid \\
\hline P22 & 0.500 & 0.279 & 50 & Valid \\
\hline P25 & 0.247 & 0.279 & 50 & Invalid \\
\hline P12 & 0.337 & 0.279 & 50 & Valid \\
\hline P6 & -0.180 & 0.279 & 50 & Invalid \\
\hline P13 & 0.141 & 0.279 & 50 & Invalid \\
\hline P8 & 0.410 & 0.279 & 50 & Valid \\
\hline P9 & 0.526 & 0.279 & 50 & Valid \\
\hline P10 & 0.490 & 0.279 & 50 & Valid \\
\hline P18 & 0.343 & 0.279 & 50 & Valid \\
\hline P23 & 0.574 & 0.279 & 50 & Valid \\
\hline P11 & 0.443 & 0.279 & 50 & Valid \\
\hline & & & & \\
\hline
\end{tabular}




\begin{tabular}{|c|c|c|c|c|}
\hline $\begin{array}{c}\text { Statement for } \\
\text { behavior } \\
\text { indicator }\end{array}$ & $\begin{array}{c}\text { r value } \\
\text { calculated from } \\
\text { analysis }\end{array}$ & $\begin{array}{c}\text { r base on } \\
\text { statically table }\end{array}$ & $\begin{array}{c}\text { Number of } \\
\text { data }\end{array}$ & $\begin{array}{c}\text { Indicator } \\
\text { value degree }\end{array}$ \\
\hline P4 & 0.564 & 0.279 & 50 & Valid \\
\hline P5 & 0.383 & 0.279 & 50 & Valid \\
\hline P16 & 0.613 & 0.279 & 50 & Valid \\
\hline P17 & 0.608 & 0.279 & 50 & Valid \\
\hline P7 & 0.502 & 0.279 & 50 & Valid \\
\hline P26 & 0.618 & 0.279 & 50 & Valid \\
\hline P27 & 0.460 & 0.279 & 50 & Valid \\
\hline
\end{tabular}

Source: Output SPSS V. 22.0, 2017

\subsection{Respondent characteristics}

Characteristics of respondents by age, it was found that the number of respondents with the age of 14 years was approximately 1 person $(0.26 \%)$, respondents aged 15 years, about 37 people $(9.44 \%)$, respondents aged 16 years amounted to 152 persons $(38.78 \%)$, respondents aged 17 years of 171 persons (43.62\%), 18-year-old respondents, 29 persons $(7.40 \%)$, and 19 -year-old respondents were 2 persons $(0.51 \%)$. The results showed that $48.47 \%$ of students aged under 17 years had ridden a motorcycle. Respondents characterized by sex found that males and females distributed almost equally. Respondents of male sex numbered 207 respondents $(52.81 \%)$ and female respondents were 185 respondents $(47.19 \%)$. Characteristics of respondents based on riding licence show that the sample of 394 respondents consisted of $12.50 \%$ of respondents who did have riding licences and as many as $87.50 \%$ did not have riding licences.

\subsection{Structural equation modelling (SEM) analysis with the AMOS program}

The SEM process cannot be performed manually. In addition to the limitations of human capabilities, the complexity of the models and statistical tools used make manual calculations inefficient. So, it's necessary to use special software for calculation. Basic statistical tools of SEM include AMOS. Models analyzed with the help of AMOS program in this study can be seen in Figure 2.

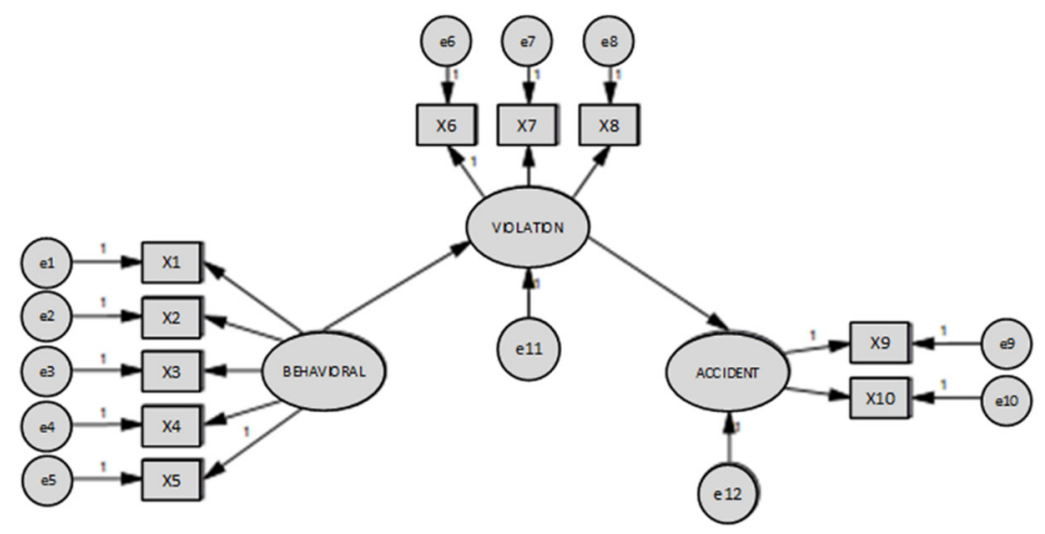

Fig. 2. The Influence model of student driving behavior on traffic accidents. 


\subsection{Modified SEM models}

In AMOS, when the SEM model is determined to not be a fit, a recommendation is given to modify the model. Recommendations for model modifications will appear on the AMOS modification indices output. The fit model test recommendation to modify model can be summarized in the following table:

Table 7. Goodness - of - fit indices of model's modification.

\begin{tabular}{|c|c|c|c|}
\hline Goodness of Fit Indices & Cut off Value & Result & $\begin{array}{c}\text { Model } \\
\text { Evaluation }\end{array}$ \\
\hline Degree of Freedom (DF) & Positive $(+)$ & 24 & Identified \\
\hline X2 (Chi square) & $\leq 38.885[=$ CHINV $(0.05,24)]$ & 27.668 & Fit \\
\hline Probability of Significance & $\geq 0.05$ & 0.274 & Fit \\
\hline CMIN DF & $\leq 2.00$ & 1.153 & Fit \\
\hline GFI & $\geq 0.90$ & 0.985 & Fit \\
\hline RMSEA & $\leq 0.05$ & 0.020 & Fit \\
\hline AGFI & $\geq 0.90$ & 0.966 & Fit \\
\hline TLI & $\geq 0.90$ & 0.992 & Fit \\
\hline NFI & $\geq 0.90$ & 0.969 & Fit \\
\hline
\end{tabular}

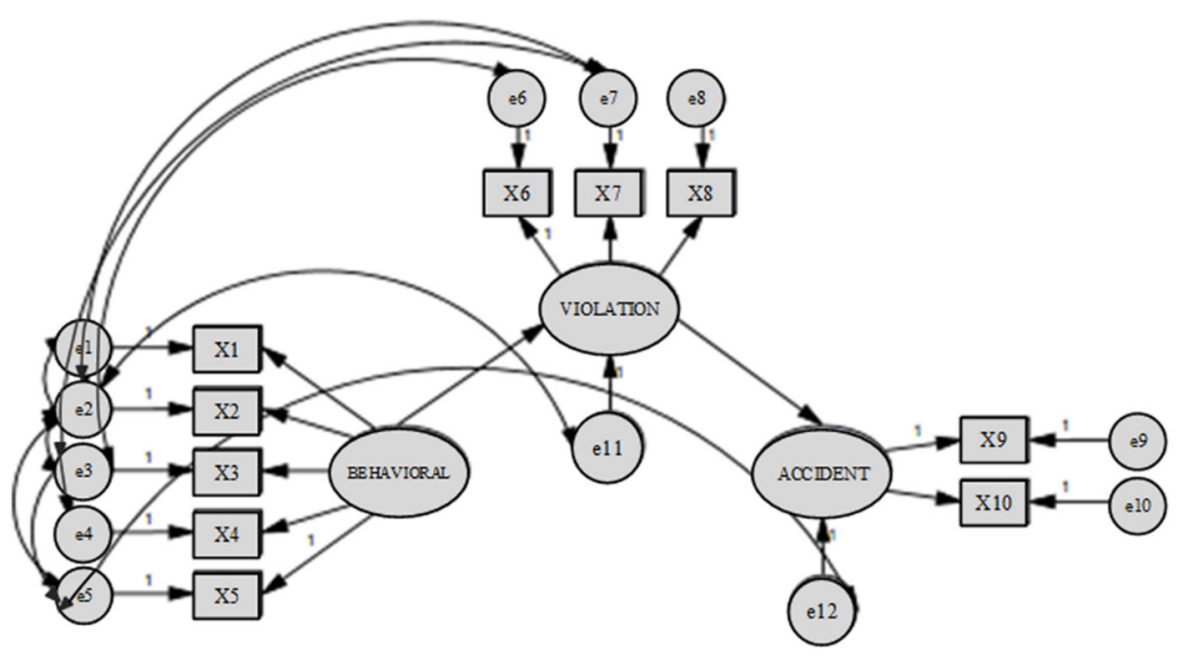

Fig. 3. SEM models after modification.

\subsection{Analysis of indicator relationship with variables and inter-variables}

The results of the data analysis of the indicator's relationship with variable and the intervariable is presented in Table 8 below: 
Table 8. Value of significance of loading factor.

\begin{tabular}{|ll|c|c|c|c|c|}
\hline & & Estimate & SE & CR & P & Label \\
\hline Violations & $\leftarrow$ driving behavior & 2.157 & 309 & 6.976 & $* * *$ & \\
\hline Accident & $\leftarrow$ violations & 0.578 & 089 & 6.507 & $* * *$ & \\
\hline X5 & $\leftarrow$ driving behavior & 1.478 & 219 & 6.750 & $* * *$ & \\
\hline X4 & $\leftarrow$ driving behavior & 1.226 & 166 & 7.400 & $* * *$ & \\
\hline X3 & $\leftarrow$ driving behavior & 1.386 & 205 & 6.757 & $* * *$ & \\
\hline X2 & $\leftarrow$ driving behavior & 0.781 & 214 & 3.656 & $* * *$ & \\
\hline X1 & $\leftarrow$ driving behavior & 1.000 & & & & \\
\hline X6 & $\leftarrow$ violations & 1.000 & & & & \\
\hline X7 & $\leftarrow$ violations & 0.780 & 078 & 9.990 & $* * *$ & \\
\hline X8 & $\leftarrow$ violations & 0.774 & 115 & 6.744 & $* * *$ & \\
\hline X9 & $\leftarrow$ accident & 1.000 & & & & \\
\hline X10 & $\leftarrow$ accident & 0.973 & 140 & 6.951 & $* * *$ & \\
\hline
\end{tabular}

\section{Regression Weights: (Group number 1 - Default model)}

From the above output display, since all $\mathrm{P}$ values are ***, it can be concluded that all indicators can explain all constructs. Likewise, there is a significant relationship between constructs. In addition to the probability value $(\mathrm{P})$, a relationship is considered significant if it has a CR (Critical Ratio) value $\geq 1.96$. In the table above, all CR values have $\geq 1.96$, indicating that the relationship between the indicator and the construct, and the relationship between constructs is significant.

Table 9. Output standardized regression weight.

\begin{tabular}{|c|c|}
\hline Relationship & estimate \\
\hline Violations $\leftarrow$ Riding behavoior & 0.439 \\
\hline Accident $\leftarrow$ Violations & 0.375 \\
\hline $\mathrm{X} 5 \leftarrow$ Behavior & 0.454 \\
\hline $\mathrm{X} 4 \leftarrow$ Behavior & 0.675 \\
\hline $\mathrm{X} 3 \leftarrow$ Behavior & 0.454 \\
\hline $\mathrm{X} 2 \leftarrow$ Behavior & 0.246 \\
\hline $\mathrm{X} 1 \leftarrow$ Behavior & 0.574 \\
\hline $\mathrm{X} 6 \leftarrow$ Violations & 0.655 \\
\hline $\mathrm{X} 7 \leftarrow$ Violations & 0.787 \\
\hline $\mathrm{X} 8 \leftarrow$ Violations & 0.416 \\
\hline $\mathrm{X} 9 \leftarrow$ Accident & 0.740 \\
\hline $\mathrm{X} 10 \leftarrow$ Accident & 0.674 \\
\hline
\end{tabular}

Source: Output of AMOS V. 22.0

In the table above, the loading factor number shown in the column estimates $>0.5$, it showing a close relationship between constructs. 
Table 10. Squared multiple correlations value.

\begin{tabular}{|l|r|}
\hline & Estimate \\
\hline VIOLATIONS & 0.814 \\
ACCIDENT & 0.285 \\
\hline
\end{tabular}

Source: Output of AMOS V. 22.0

The estimate value of the variable violations is shown in table 9 above [0.814], can be interpreted that the BEHAVIOR variable affects $81.4 \%$ of the VIOLATIONS variable, while the rest $(100 \%-81.4 \%=18.6 \%)$ was influenced by other factors, indicated by error (e11) where the variable is outside this study. Similarly, the number 0.285 can be interpreted as a VIOLATIONS variable affecting $28.5 \%$ of the ACCIDENT variables while the rest is indicated by error (e12). The table above shows only indicator X9 and X7 have influence above $50 \%, 54.8 \%$ and $62 \%$, respectively. On one hand, the analysis of sex and age also shows differences in the value of significance (chi-square) between the relationships of "behavioral" with "violation". The other hand, Gender and age variables also show differences in the significance (chi-square) values of riding behavior to traffic violations and accidents. From 195 male respondent and 179 female respondents, the analysis showed the significance of the effect of driving behavior to violations and accidents was $6 \%$ lower with women drivers. The students under the 17-year olds are more sensitive to traffic violations than others

\section{Conclusions}

Based on data analysis and discussions, a few main conclusions can be made:

1. More than $87.5 \%$ of the students' motorcycle riders in Mataram City do not have riding licenses.

2. $51.53 \%$ of the respondents were above 17 years old and had been involved in a traffic accident, and $6 \%$ difference of influences riding behavior to violations and accidents

3. This study indicates significant relationships between student riding behavior and traffic violations and between traffic violations and accidents as well.

4. There is a significant difference (chi-square) between behavior and violations when considering age and gender.

\section{References}

1. Anonim, Undang-undang Republik Indonesia Nomor 22 Tahun 2009 tentang Lalu Lintas dan Angkutan Jalan, Jakarta (2009) (in Indonesia).

2. Anonim, Sekolah kita. http://sekolah.data.kemdikbud.go.id, 27-01 -017 (in Indonesia)

3. P. Dwiyogo, Prabowo, Semarang: Universitas Diponegoro. (2006) (in Indonesia).

4. I. Ghazali, I, Universitas Diponegoro, Semarang. (2011) (in Indonesia).

5. S. Santoso, PT Elex Media Komputindo, Jakarta. (2014) (in Indonesia).

6. D.W. Ikroom, Universitas Bengkulu, (2014) (in Indonesia)

7. Sugiyono, Alfabeta, Bandung. (2010) (in Indonesia).

8. Wesli, Teras Jurnal, Vol. 5, No. 1, Maret 2015, p. 43-50. (2015) (in Indonesia).

9. J. Bergdahl, The Social Science Journal, 42, 595-601) (2005)

10. J. Bergdahl, M.R. Norris, M. R, The Social Science Journal, 39, 287-293) (2002) 